\title{
最大風速半径を考慮した可能最大高潮 の長期変動予測
}

\author{
吉野 純 1 - 高島 利紗 2 -小林 智尚 3 \\ 1正会員 岐阜大学准教授 大学院工学研究科（广501-1193 岐阜県岐阜市柳戸1-1） \\ E-mail:jyoshino@gifu-u.ac.jp \\ 2学生会員 岐皁大学 大学院工学研究科（广501-1193 岐阜県岐阜市柳戸1-1) \\ 3 正会員 岐皁大学教授 大学院工学研究科（广501-1193 岐阜県岐阜市柳戸1-1）
}

\begin{abstract}
本研究では, 可能最大強度（MPI）に達した台風がもたらす可能最大高潮（MPSS）を高効率かつ高精度 に評価すること目的として，MPIの変化のみならず最大風速半径（RMW）の変化をも考慮できる新しい MPI台風一高潮結合モデルを構築した。CMIP3が提供する全球気候モデルHadCM3の結果を用いて，伊勢 湾におけるMPSSの長期変動を, MPIのみを考慮する場合（CASE1）とMPIとRMWの両方を考慮する場合

（CASE2）に別けて評価した。 その結果，名古屋港におけるMPSSの100年間上昇量は，CASE1の場合， B1シナリオで $+2.5 \mathrm{~m}, \mathrm{~A} 2$ シナリオで+3.2m となるのに対して, CASE2の場合, B1シナリオで $+3.2 \mathrm{~m}, \mathrm{~A} 2$ シ ナリオで+3.9mとなり, MPSSの評価に際してRMWを適切に考慮することの重要性が明らかとなった。
\end{abstract}

Key Words : global warming projection, typhoon, maximum potential intensity, radius of maximum wind speed, maximum potential storm surge

\section{1. はじめに}

地球温暖化に伴う台風強大化が䀣念される中, 強大化 した台風による最悪規模の高潮に備えたハード面とソフ 卜面での対策の見直しが火急的課題となっている．著者 らの一連の研究1223344 において, 発達し得る最大の強度 (MPI : Maximum Potential Intensity) にまで成長した台風 （以降，MPI台風）が最悪の進路で上陸することでもた らされる最悪規模の高潮 (MPSS : Maximum Potential Storm Surge）を評価している．伊勢湾台風時（1959年9月） の台風環境場を想定した現在気候アンサンブル実験によ り，上陸時中心気圧 $930 \mathrm{hPa} の \mathrm{MPI}$ 台風が名古屋港に $5.6 \mathrm{~m}$ のMPSSをもたらし，一方で，2099年9月（A1Bシナリオ） を想定した擬似温暖化アンサンブル実験により，上陸時 中心気圧905hPaのMPI台風が名古屋港に6.9 mのMPSSをも たらし，今世紀末における温暖化の影響は無視できない 規模となることを指摘している.

これらの既往研究では，「台風渦位ボーガス」5 「大気一海洋一波浪結合モデル」のといった大気海洋力 学的な手法に基づいているため, 信頼度の高い影響評価 ができるというメリットがある反面, 極めて計算コスト が高く多量の計算が行えないというデメリットもある. そのため, 台風のMPIやMPSSに関して, 過去気候から 将来気候にわたる長期間変動や様々な温暖化シナリオに
よる温暖化影響量の差についてまでは依然として解明さ れていないのが現状である.

そのような背景の中, 吉野らわでは, 計算精度を落と すことなく大幅に計算コストの低下を実現したMPI台風 一高潮結合モデルを開発し，温暖化シナリオ毎に21世紀 100年間の名古屋港におけるMPSSの評価に成功している. この手法では, 計算の簡略化のために経験的台風モデル を用いていることから，高潮偏差に大きな影響を及ぼす 重要な属性パラメータとして台風の中心気圧 (MPI) と 最大風速半径（RMW : Radius of Maximum Wind speed）を 適切に設定することが要求される.しかしながら，この 先行研究では, RMWとしては台風渦位ボーガスによっ て推定された $30 \mathrm{~km}$ 固定值として設定しているため, MPSSの推定結果に対寸る量的な信憑性については依然 として疑問が残る。台風のRMWは, 絶対角運動量保存 則を介して台風強度とも密接に関係しているため8)，高 潮偏差に大きく影響する重要な属性パラメータとなるこ とから, MPIの将来変化のみならずRMWの将来変化を も考慮した高精度な評価手法へと改良していくことが要 求される.

そこで本研究では，MPIのみならずRMWをも考慮で きる新しいMPI台風一高潮結合モデルを開発することに より, 台風の最盛期時および上陸時のMPIを評価すると 共に，RMWを考慮に入れた名古屋港のMPSS の長期変動 


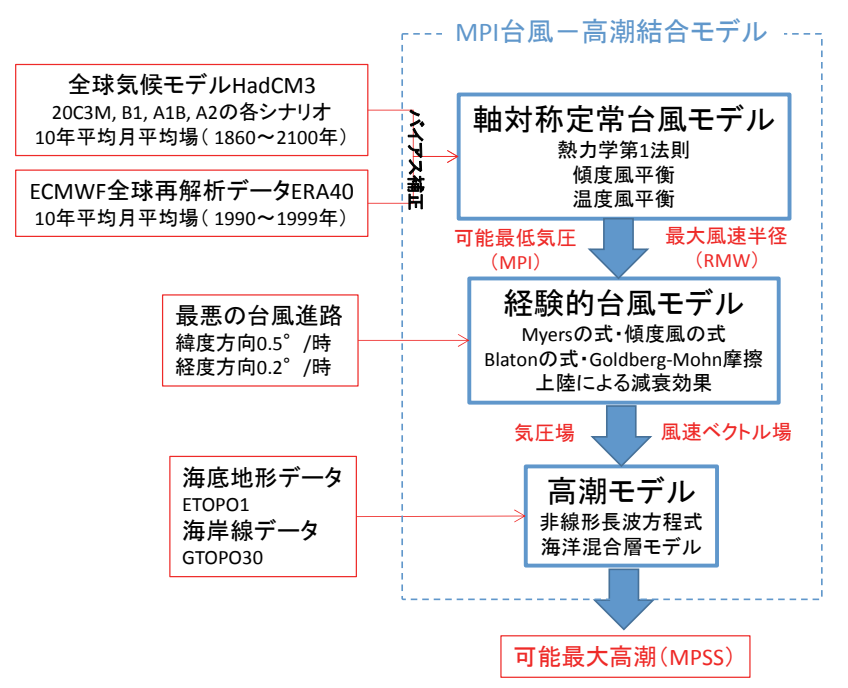

図-1ＭPI台風一高潮結合モデルの計算フロー

を温暖化シナリオ毎に評価することを目的とする.

\section{2. 数値計算の方法}

本研究では, MPI台風一高潮結合モデルわに対して, RMWの効果を加味できるような改良を加え，図-1の計 算フローにより台風のMPIおよびMPSSの評価を行う.

\section{(1) 軸対称定常台風モデル}

はじめに，与えられた台風環境場における台風の可能 最大強度（MPI）を評価するために，Bister らにより開 発された定常軸対称台風モデルを使用する. このモデル は, 最大風速半径 $r_{m}$ での最大風速（傾度風） $V_{m}$ と海面 気圧 $P_{m}$ に関する以下の式(1)と(2),

$$
\begin{gathered}
\left|V_{m}\right|^{2}=\frac{C_{k}}{C_{D}} \frac{T_{s}}{T_{0}}\left[C A P E^{*}-C A P E\right] \\
R T_{s} \ln \left(\frac{P_{0}}{P_{m}}\right)=C A P E+\frac{1}{2} V_{m}^{2}
\end{gathered}
$$

を基礎方程式としている． $T_{s}$ は海水面温度， $T_{0}$ は対流 圈界面温度， $C_{k}$ は海面における熱交換係数， $C_{D}$ は海 面における運動量交換係数を示している. CAPE*は海 面における飽和空気を持ち上げた時の潜在有效位置エネ ルギーであり，CAPE は境界層内の湿潤空気を持ち上 げた時の潜在有効位置エネルギー， $P_{0}$ は環境場におけ る海面気圧（=1000 hPa），Rは乾燥空気の気体定数で ある．台風環境場データを設定し，これらの連立方程式 を解くことで，理論的に MPI 台風の海面気圧 $P_{m}$ を得る. また, 最大風速半径 $r_{m}$ は, Emanuel ${ }^{10)}$ に基づいて, 以 下の式(3)と(4),

$$
r_{m}=r_{a}\left[\frac{4 R T_{s}}{f^{2} r_{a}^{2}} C(1+C) \ln \left(\frac{P_{0}}{P_{m}}\right)\right]^{-\frac{1}{2 C}}
$$

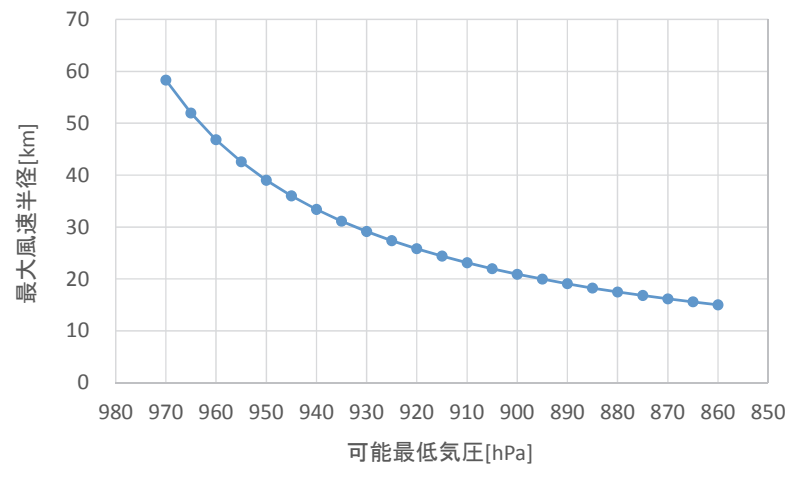

図-2 可能最低気圧と最大風速半径の関係

$$
C=1-\frac{T_{s}-T_{0}}{T_{s}}\left(1+\frac{L_{v} w_{a}}{R T_{s}}\right)
$$

によって理論的に評価できる，ここで， $r_{a}$ は台風の影 響半径で $\left(r_{a}>>r_{m}\right) ， w_{a}$ は台風の影響半径における 水蒸気混合比， $L_{v}$ は凝結の潜熱を示す．同様に台風環 境場データを設定し，この最大風速半径 $r_{m}$ に関する式 を解くことで MPI 台風の RMW とする. ここでは式(3) と(4)に対して, $r_{a}=500[\mathrm{~km}], T_{s}=27\left[{ }^{\circ} \mathrm{C}\right], T_{0}=-73\left[{ }^{\circ} \mathrm{C}\right]$, $f=7.29 \times 10^{-5}[1 / \mathrm{s}]$ （緯度 30 度），相対湿度 $R H=80$ [\%] 設定すると，図-2 のように MPI と RMW の関係が得ら れる，過去の観測的研究が指摘するように ${ }^{11)}$, 台風強度 が強まれば強まるほど，絶対角運動量保存則を満たすよ

うにRMWは小さくなる傾向にある。

\section{（2）経験的台風モデル}

次に，「経験的台風モデル」により MPI 台風の台風 気象場を推定する。このモデルは，気圧場に対する Myers の式と風速ベクトル場に対する傾度風の式により 構成される 2 次元の経験的台風モデルである. 風速べク トル場に対する台風移動効果には Blaton の式を，地表面 摩擦効果には Goldberg-Mohn 摩擦を仮定し, 風速べクト ルの吹き込み角度は海上に典型的な $10^{\circ}$ としている。 軸対称定常台風モデルにより評価された MPI が計算初 期の台風強度として入力されるが，一般的に，上陸後の 台風は MPI の勢力を保ったままではなく，急激にその 強度を減じるため, 上陸後の台風強度減衰を適切に組み 込む必要がある.

そこで本研究では, 先行研究に倣って》, MPI 台風が 上陸前については勢力を維持すると仮定し，上陸後につ いては台風強度減衰パラメタリゼーションを部分上陸と 完全上陸に別けて適用する. ここで，部分上陸時の中心 気圧の時間変化 $d P / d t \quad[\mathrm{hPa} /$ 時 $]$ は,

$$
\frac{d P}{d t}=0.1956\left(P-P_{m}\right)
$$




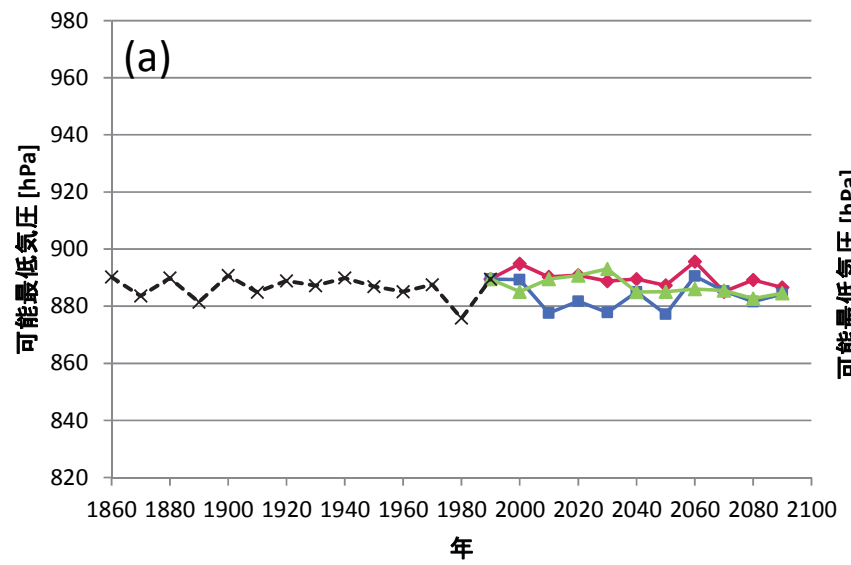

図-3 各温暖化シナリオの年最低可能最低気圧の時系列:

とする． $P$ は中心気圧 $[\mathrm{hPa}], P_{m}$ は台風上陸時の中心 気圧である.また, 完全上陸後の中心気圧の時間変化 $d P / d t \quad[\mathrm{hPa} /$ 時 $]$ は,

$$
\frac{d P}{d t}=-0.0635 z_{0}^{0.1853}(P-1000)
$$

とする.ここで， $z_{0}$ は陸上の粗度長であり，本研究で は $z_{0}=50[\mathrm{~cm}]$ に設定した．粗度長の大きな陸面であるほ ど強度減衰の変化率はより大きくなる．この経験的台風 モデルの利用により，既往研究のように 3 次元のメソ気 象モデルによる時間発展を計算する必要がなくなるため 大幅に計算コストを下げることができる.

\section{(3) 高潮モデル}

最後に，「高潮モデル」は，鉛直1層の非線形長波方 程式（運動方程式および連続式）により構成され，運動 方程式は移流項，コリオリ項，水面勾配項，圧力勾配項， 風応力項, 底面摩擦項, および, 水平拡散項が考慮され ている. 水平格子間隔は1.0 km×1.0 kmとして, 海底地 形データにはETOPO1（1分間隔）, 海岸線データには GTOPO30（30秒間隔）を使用する．経験的台風モデル により評価されたMPI台風の気圧場および風速べクトル 場が入力され, Garratの海面抵抗係数式に基づいて風応 力項が計算される. 底面摩擦係数は $2.6 \times 10^{3}$, 水平渦拡 散係数は $3.0 \times 10^{-3}\left[\mathrm{~m}^{2} / \mathrm{s}\right]$ とする. また, 数值積分の時間ス テップ幅は2秒とする.この高潮モデルの利用により， 既往研究のように3次元の海洋モデルによる時間発展を 計算する必要がないため同様に大幅に計算コストを下げ ることができる.

以上のMPI台風一高潮結合モデルを用いて，1959年9月 26日に伊勢湾台風の再現計算を行ったところ》, 名古屋 港での最大風速は $39 \mathrm{~m} / \mathrm{s}$ （観測 $37 \mathrm{~m} / \mathrm{s}$ ），最低海面気圧は $962 \mathrm{hPa}$ (観測963 hPa），最大潮位偏差は3.6m（観測 3.55m）となり，その再現性の良さを実証できている.

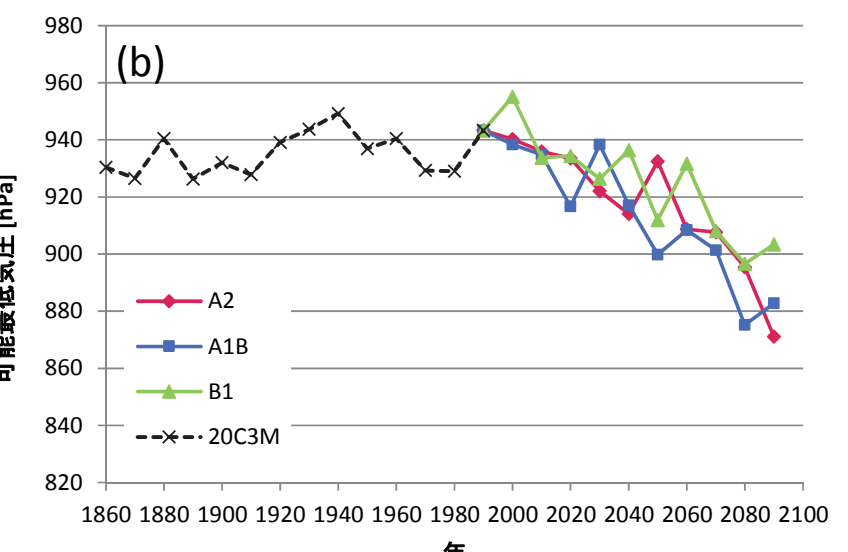

年

: (a)伊勢湾台風の最盛期地点, (b)伊勢湾台風の上陸地点.

\section{(4) 使用したデータと計算設定}

本研究では，このMPI台風一高潮結合モデルを用いて， 伊勢湾湾奥に位置する名古屋港を対象として，MPSSの 長期変動を温暖化シナリオ毎に評価する.

軸対称定常台風モデル（2.1節）に入力する台風環境 場データは，CMIP3マルチ気候モデルデータの1つであ る全球気候モデルHadCM3の将来予測データである. 下 端1000 hPaから上端70 hPaまでの水平格子間隔2.5 $\times$ $3.75^{\circ}$ からなる1ヶ月平均格子点データ (気温, 相対湿 度，ジオポテンシャル高度，地表面気圧，および，海水 面温度）に対して月毎に10年間平均值を作成して使用す る. 過去・現在気候（1860～1999年）に対しては， 20C3M（産業革命以降の温室効果ガスの排出データ）を， 将来気候（2000～2100年）に対しては，A2（今世紀末の 大気中の二酸化炭素濃度 $1250 \mathrm{ppm}$ となる排出シナリオ), A1B（同850 ppmとなる排出シナリオ），および，B1 （同600 ppmとなる排出シナリオ）を入力データとする. ただし，これらの入力データに対して，水平格子間隔 $2.5^{\circ} \times 2.5^{\circ}$ からなるECMWF再解析データERA40の1990 〜1999年までの月毎の10年間平均值を用いてバイアス補 正を施している. 本研究では, 伊勢湾台風の最盛期地点 (北緯19.7 ，東経141.7 ） と上陸地点（北緯33.44 ， 東経 $135.75^{\circ} ） の$ 最寄り格子点を対象として, 台風の MPIの長期変動について解析を行う（3.1節）。

得られた伊勢湾台風上陸地点のMPIを経験的台風モデ ル（3.2節）に入力し，得られた台風気象場を外力条件 とすることで, 最終的に, 高潮モデル（3.3節）により MPSSの評価を行う。計算設定の詳細は先行研究》の設定 をベースとし, 名古屋港に上陸・接近するMPI台風に対 して，伊勢湾台風の最接近時の移動方向と移動速度（緯 度方向 $0.5^{\circ}$ /時, 経度方向 $0.2^{\circ}$ /時）に基づき, 一定から 一直線的な台風進路を設定する。本研究では, RMWの 設定がMPSSに及ぼす影響について評価するため, 次の2 種類の数值実験を実施する（3.2節）. CASE1（従来手 法）では，RMWを伊勢湾台風と同等の75kmとし，最接 
表-1 各温暖化シナリオの年最低可能最低気圧，年最高海水面温度，および，年最高 300hPa気温に関する線形回帰トレンド

\begin{tabular}{|c|c|c|c|c|c|}
\hline \multicolumn{2}{|l|}{ 物理量 } & $\begin{array}{c}20 \mathrm{C} 3 \mathrm{M} \\
(1860-2000)\end{array}$ & $\begin{array}{c}\mathrm{B} 1 \\
(2000-2090)\end{array}$ & $\begin{array}{c}\text { A1B } \\
(2000-2090)\end{array}$ & $\begin{array}{c}\mathrm{A} 2 \\
(2000-2090)\end{array}$ \\
\hline \multirow{2}{*}{$\begin{array}{l}\text { 可能最低気圧 } \\
{[\mathrm{hPa} / 100 \text { 年] }}\end{array}$} & 最盛期地点 & -2.12 & -5.79 & -1.56 & -4.07 \\
\hline & 上陸地点 & 6.31 & -48.20 & -64.56 & -60.36 \\
\hline \multirow{2}{*}{$\begin{array}{c}\text { 海水面温度 } \\
{\left[{ }^{\circ} \mathrm{C} / 100 \text { 年 }\right]}\end{array}$} & 最盛期地点 & 0.27 & 1.48 & 1.98 & 2.34 \\
\hline & 上陸地点 & -0.24 & 3.59 & 4.45 & 4.65 \\
\hline \multirow{2}{*}{$\begin{array}{c}300 \mathrm{hPa} \text { 気温 } \\
{\left[{ }^{\circ} \mathrm{C} / 100 \text { 年 }\right]}\end{array}$} & 最盛期地点 & 0.75 & 3.67 & 6.13 & 6.05 \\
\hline & 上陸地点 & -0.20 & 4.26 & 6.40 & 5.33 \\
\hline
\end{tabular}

近時に伊勢湾台風と同等の進路をとるように初期中心位 置を調整して行う実験である。また, CASE2（新手法） では，RMWを式(3)と(4)により評価し，最接近時に台風 中心右側の最大風速域が名古屋港に直撃するように初期 中心位置を調整して行う実験である.いずれのケースも, 温暖化シナリオ毎に36時間積分を合計864回（12ケ月×24 年代×3シナリオ）繰り返す。また，バイアス補正を行わ ないHadCM3の将来予測データから同地点の年最低MPI に対して10年毎に標準偏差（年々変動の大きさ）を評価 し，バイアス補正されたMPIに対して +10 と-10 を加算 よる高潮計算も行うことで, MPI MPSSの年々変動の 大きさについても議論する.

\section{3. 結果と考察}

\section{(1) 可能最大強度の長期変動予測}

まず，伊勢湾において既往最大潮位をもたらした伊勢 湾台風を想定することで, 伊勢湾台風の最盛期地点と伊 勢湾台風の上陸地点の2箇所における, 年最低MPIの長 期変動とMPIの季節変化について解析を行った（図-3,

図-4，および，表-1).

まず，伊勢湾台風の最盛期地点における年最低MPIに ついては（図-3(a)），1860～2000年の過去・現在気候で は約890hPa程度であり，2000～2090年の将来気候ではど の温暖化シナリオであっても明瞭なトレンドを確認する ことはできない（表-1）。また，伊勢湾台風の上陸地点

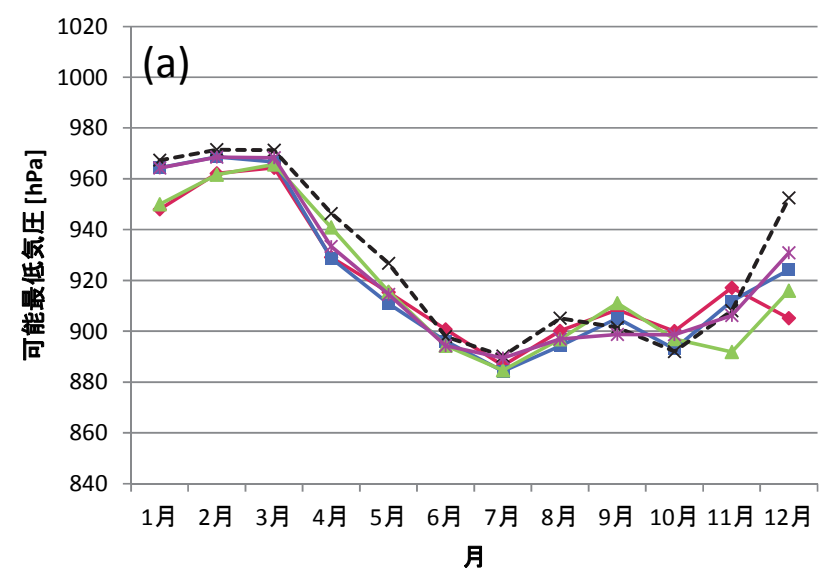

における年最低MPIについては（図-3(b)），1860～2000 年の過去・現在気候では同様に明瞭なトレンドは見られ ず，およそ930hPa前後で安定している.この数值は, 1959年に上陸した伊勢湾台風の上陸時の中心気圧 (929hPa) とよく整合している. 2000年以降の将来気候 においては，いずれの温暖化シナリオにおいてもMPIは 徐々に増大する傾向にあり，B1では-48hPa/100年，A2で は-60hPa/100年となり，温暖化の進行がより大きなシナ リオであるほど上陸時MPIは増大する傾向にある（表1）. 先行研究でも指摘》,12)するように，温室効果ガスの 排出量が加速的に増大する場合（A2），熱帯海上（最 盛期地点）では，海水面温度 $T_{s}$ の上昇量（ $\mathrm{A} 2$ は $+2.3^{\circ} \mathrm{C}$ $/ 100$ 年）に比べて，300hPa気温 $T_{0}$ の上昇量（A2は $+6.1^{\circ} \mathrm{C} / 100$ 年) の方がかなり大きいため, 式(1)と(2)より， 必ずしもMPIが増大するわけではない。一方で, 中緯度 海上（上陸地点）では， $300 \mathrm{hPa}$ 気温 $T_{0}$ の上昇量（A2は $+5.3^{\circ} \mathrm{C} / 100$ 年）に匹敵する規模で海水面温度が上昇（A2 は+4.7C/100年) するため, MPI台風はより強化されやす いものと考察される.

また，伊勢湾台風の最盛期地点におけるMPIの季節変 化については（図-4(a)），6月～10月の台風シーズンに おいては温暖化による影響はほとんど受けていないが, 11月〜5月の台風のオフシーズンには温室効果ガスの排 出量が増すほどMPIが強化される傾向にあり, 温暖化に より台風シーズンがより長くなる可能性が示唆される. また，伊勢湾台風の上陸地点におけるMPIの季節変化に

図-4 各温暖化シナリオの可能最低気圧の季節变化:(a)伊勢湾台風の最盛期地点, (b)伊勢湾台風の上陸地点.

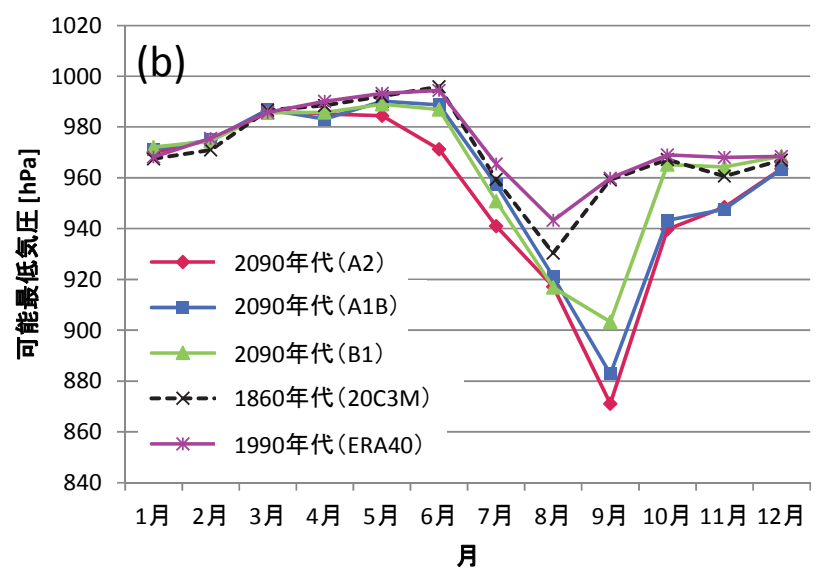



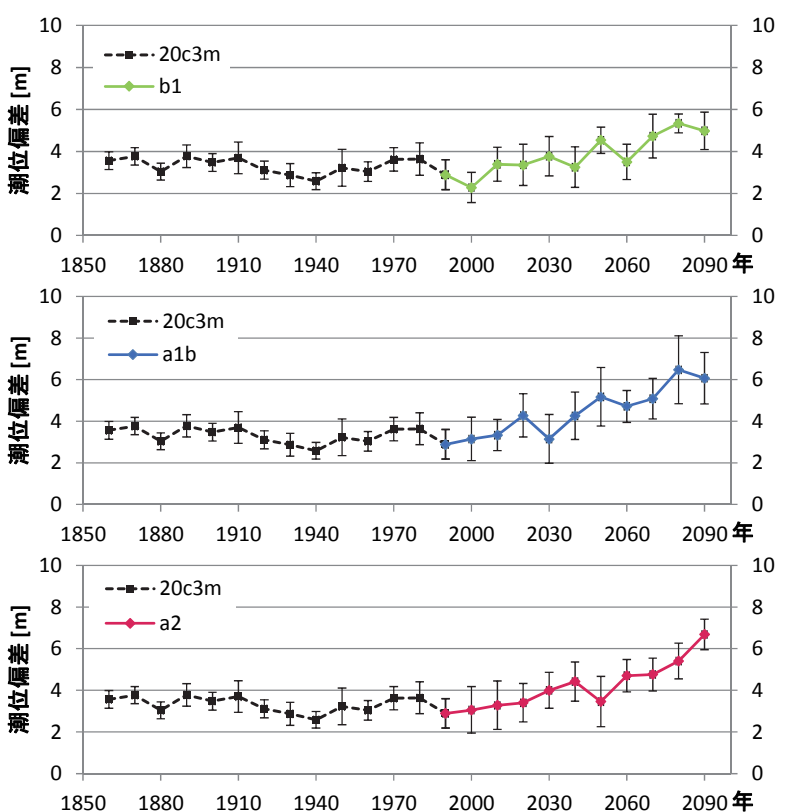

図-5＼cjkstart名古屋港における各温暖化シナリオの年最高可能最

大高潮（CASE1）。エラーバーは10年毎の標準偏差.

ついては（図-4(b)），温暖化の進行に伴い特に9月にお ける上陸時MPIが顕著に増大寸る傾向が明瞭に見て取れ る. MPIが940hPaを下回る期間について着目すると，過 去気候（1860年代）では1ヶ月間のみにとどまるのに対 して，B1（2090年代）では2ヶ月間，A2（2090年代）で は4ヶ月間となり，強い勢力を有する台風の上陸リスク が増大寸る傾向にあると言える。

\section{(2) 可能最大高潮の長期変動予測}

次に，年最低 MPI を外力とする台風が最悪の進路で 伊勢湾湾奥の名古屋港に上陸・接近した場合に生じる年 最高 MPSS の長期変動を評価し，RMW を一定とする CASE1 と RMW の変化を考慮する CASE2 を比較を行っ た（図-5，図-6，および，表-2）。

まず，過去・現在気候においては，CASE1 では名古 屋港の MPSS は約 3.5m であり（図-5），1959 年 9 月に 名古屋港で観測された最大潮位偏差（3.55m）とよく整 合している．また，将来気候においては，図-3(b)と同 様に, CASE1 と CASE2 共に温暖化の進行と共に増大寸 る傾向にあることが見て取れる，RMW を固定する
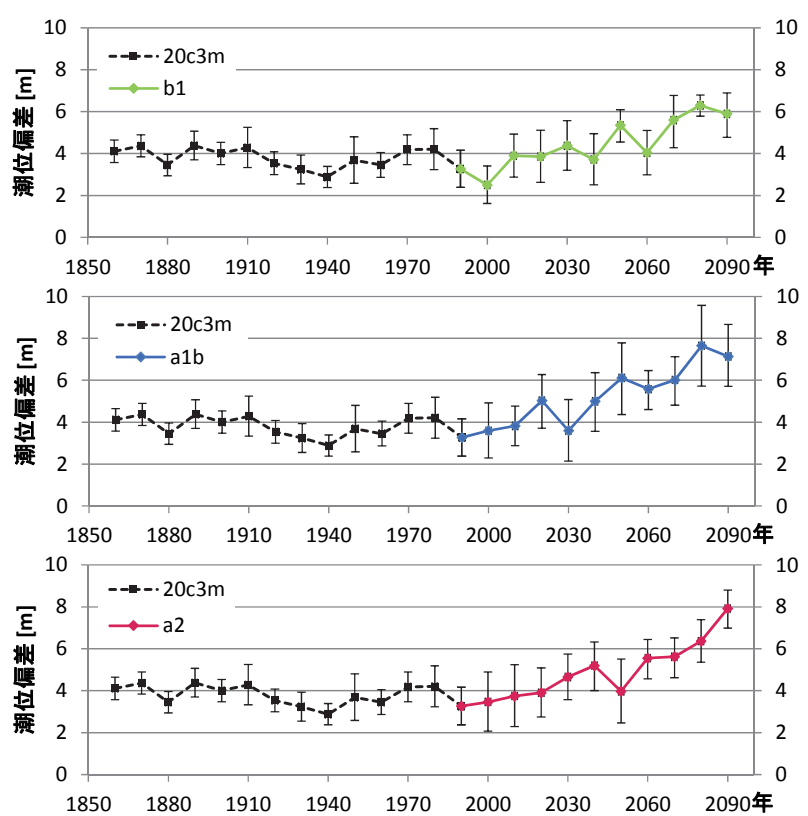

図6 名古屋港における各温暖化シナリオの年最高可能最 大高潮（CASE2）。エラーバーは 10年毎の標準偏差.

CASE1 に比べて RMW の変動を考慮した CASE2 の方が MPSS がより大きく評価される傾向にあることが特徵的 である（図-6）。CASE1 の名古屋港での可能最大高潮 の 100 年間上昇量は，CASE1 の場合，B1 で+2.5m/100 年， A2 で+3.2m/100 年の上昇を, CASE2 の場合, B1 で $+3.2 \mathrm{~m} / 100$ 年, $\mathrm{A} 2$ で $+3.9 \mathrm{~m} / 100$ 年の上昇を示し（表-1）, MPSS の評価の際には RMW の変化が無視できない影響 を及ぼしていることが明らかとなった。

また, 年最低 MPI の年々変動の大きさを表す標準偏 差も（表-2），温暖化の進行に伴って増大寸る傾向があ り, 結果として, MPSS の標準偏差も温暖化の進行によ り過去・現在気候の約 $0.7 \mathrm{~m}$ から, 将来気候（2090 年代 A1B ）には約 $1.4 \mathrm{~m}$ 程度にまで増大寸る。つまり, 将来 気候下においては， $-1 \sigma$ で $5.5 \mathrm{~m}$ 程度, 平均で $7 \mathrm{~m}$ 程度, 最悪の条件が重なる +10 では $8.5 \mathrm{~m}$ に迫る潮位偏差がも たらされる可能性があることを意味している．大気海洋 力学的な手法に基づいた先行研究 122,3,344による推定值 （2090 年代 A1B）は，およそこれらの範囲内に収まっ ていることから，本研究の簡易的手法であっても妥当な 結果が得られたと見なせる.

表-2 各温暖化シナリオの年最低可能最低気圧と年最高可能最大高潮に関する線形回帰トレンドと 10 年間標準偏差の平均

\begin{tabular}{|c|c|c|c|c|c|}
\hline \multicolumn{2}{|l|}{ 物理量 } & $\begin{array}{c}20 \mathrm{C} 3 \mathrm{M} \\
(1860-2000)\end{array}$ & $\begin{array}{c}\text { B1 } \\
(2000-2090)\end{array}$ & $\begin{array}{c}\text { A1B } \\
(2000-2090)\end{array}$ & $\begin{array}{c}\text { A2 } \\
(2000-2090)\end{array}$ \\
\hline \multirow{2}{*}{$\begin{array}{c}\text { 上陸地点の } \\
\text { 可能最低気圧 }\end{array}$} & 線形回帰トレンド[hPa/100年] & 6.31 & -48.20 & -64.56 & -60.36 \\
\hline & 10年間標準偏差の平均[hPa] & 10.6 & 15.8 & 21.3 & 17.9 \\
\hline \multirow{2}{*}{$\begin{array}{c}\text { CASE1 } \\
\text { 可能最大高潮 } \\
\end{array}$} & 線形回帰トレンド[m/100年] & -0.33 & 2.52 & 3.39 & 3.17 \\
\hline & 10年間標準偏差の平均[m] & 0.55 & 0.83 & 1.12 & 0.94 \\
\hline \multirow{2}{*}{$\begin{array}{c}\text { CASE2 } \\
\text { 可能最大高潮 }\end{array}$} & 線形回帰トレンド[m/100年] & -0.41 & 3.16 & 4.16 & 3.92 \\
\hline & 10年間標準偏差の平均[m] & 0.70 & 1.02 & 1.36 & 1.16 \\
\hline
\end{tabular}




\section{4. 結語}

台風の最大風速半径の設定は高潮推算に大きな感度を 有するため, 特に可能最大高潮の評価に際しては最大風 速半径を現実的な值に設定することが重要となってくる. 本研究では，最大風速半径を考慮できる新たなMPI台風 一高潮結合モデルを開発し，伊勢湾における可能最大高 潮の長期変化を温暖化シナリ才毎（B1，A1B，および, A2）の評価を行った.

まず，名古屋港に最悪の進路で上陸・接近するMPI台 風を想定し，まず，上陸地点近傍（潮岬付近の海域）に おけるMPIの長期変動について解析した．1860～2000年 の過去・現在気候においては明瞭なトレンドは見られず， 可能最低気圧は平均的には930hPaを示した。2000年〜 2100年の将来気候においては，いずれの温暖化シナリオ であってもMPIは可能最低気圧は減少する傾向にあり， 温暖化が進行するほど上陸時の台風強度は増す傾向を示 した。また，温暖化が進行するにつれて可能最低気圧 940hPaを下回る期間は，過去・現在気候においては1ヶ 月間なのに対して，将来気候（A2）では4ケ月間と長期 化する可能性があることも明らかとなった.

次に, 年最低可能最低気圧を外力条件として伊勢湾に おける可能最大高潮の長期変動について解析した。 その 際, 可能最低気圧の変化のみを考慮し最大風速半径は伊 勢湾台風時の75kmに固定するケース（CASE1）と，可 能最低気圧と最大風速半径の両方の変化を考慮するケ一 ス（CASE2）を比較した。伊勢湾湾奥の名古屋港におい て将来気候（A2）の可能最大高潮の線形回帰卜レンド （100年間の平均的上昇量）は, CASE1の場合は $+3.2 \mathrm{~m} / 100$ 年間の上昇を, CASE2の場合は+3.9m/100年間の 上昇を示し, 可能最大高潮の評価の際に最大風速半径を 適切に考慮することの重要性が明らかとなった.

\section{参考文献}

1) 吉野純, 岩本学士, 安田孝志: 地球温暖化の力学的 影響評価のための台風渦位ボーガスの改良, 土木学 会論文集 B2 (海岸工学), Vol.67, No.2, pp.416-420, 2011.

2) 吉野純, 岩本学士, 村上智一, 安田孝志 : 台風渦位 ボーガスに基づく東京湾地域における可能最大風速 の大気力学的評価, 土木学会論文集 B2 (海岸工学), Vol.67, No.2, pp.411-415, 2011.

3) 村上智一, 深尾宏矩, 吉野純, 安田孝志: 現在気候 の下での最大級台風による伊勢湾の可能最大高潮, 土木学会論文集 B3 (海洋開発), Vol.67, No.2, pp.985990, 2011.

4) 村上智一, 深尾宏矩, 吉野純, 安田孝志 : 温暖化シ ナリオ A1B の下で今世紀末に予想される最大級台風 による伊勢湾全域の高潮・高波，土木学会論文集 B2 (海岸工学), Vol.67, No.2, pp.406-410, 2011.

5) 吉野純, 岩本学士, 安田孝志: 地球温暖化の力学的影 響評価のための台風渦位ボーガスの改良, 土木学会 論文集 B2 (海岸工学), Vol.67, No.2, pp.416-420, 2011.

6) 村上智一, 安田孝志, 大澤輝夫 : 気象場と結合させた 湾内海水流動計算のための多重 $\sigma$ 座標モデルの開発, 海岸工学論文集, 第 51 巻. pp.366-370, 2004.

7) 吉野純, 高島利紗, 小林智尚: 気候変動を考慮した可 能最大高潮の長期変動予測技術の開発, 土木学会論文 集 B2 (海岸工学), Vol.70, No.2, pp.I_1251-I_1255, 2014.

8)山岬正紀 : 台風一最もはげしい大気擾乱一, 東京堂 出版, 206p., 1982.

9) Bister, B. and K. A. Emanuel: Low frequency variability of tropical cyclone potential intensity. 1. Interannual to interdecadal variability, J. Geophys. Res., Vol.107, 4801, 2002.

10) Emanuel, K. A.: The maximum intensity of hurricanes, $J$. Atmos. Sci., Vol.45, pp. 1143-1155, 1988.

11) Shea, D. J. and W. M. Gray: The hurricane's inner core region. I. Symmetric and asymmetric structure, J. Atmos. Sci., Vol.30, pp.1544-1564, 1973.

12) 吉野純, 荒川悟, 豊田将也, 小林智尚: 高解像度台風 モデルによる台風強度に対する温暖化影響のシナリ 才間相互比較, 土木学会論文集 B2 (海岸工学), Vol.71, No.2, pp.I_1519-I_1524, 2015.

(2016.3.16 受付)

\title{
LONG-TERM PROJECTIONS FOR MAXIMUM POTENTIAL STORM SURGE WITH CONSIDERING RADIUS OF MAXIMUM WIND SPEED
}

\author{
Jun YOSHINO, Risa TAKASHIMA and Tomonao KOBAYASHI
}

In this study, we evaluate the long-term variability of the maximum potential storm surge height induced by a mature typhoon reaching to the maximum potential intensity (MPI), with considering the radius of maximum wind speed (RMW). Two cases of the maximum potential storm surge height in Ise Bay are analyzed using HadCM3 in the CMIP3 multi-model dataset. In CASE1, the change of MPI is only included, and in CASE2, the changes of both MPI and RMW are considered. The evaluated 100-year trends in the 21 st century are $+2.5 \mathrm{~m}$ for B1 scenario and $+3.2 \mathrm{~m}$ for A2 scenario in CASE1, and $+3.2 \mathrm{~m}$ for B1 scenario and $+3.9 \mathrm{~m}$ for A2 scenario in CASE2. The results suggest that an appropriate setting of RMW in a mature typhoon especially makes much difference in predicting the long-term variability of the maximum potential storm surge height under the future climate. 